\title{
Analysis of the usefulness of the mineral composition of diets and the effectiveness of the use of mineral and vitamin supplements in the diets of cows of different technological groups
}

Galina Ulivanova, Olga Fedosova*, Olga Karelina, Vitaly Kulakov, Elman Saitkhanov

FSBEI HE RSATU, Ryazan, Russian Federation

\begin{abstract}
The paper presents the results of the analysis of the usefulness of the mineral composition of diets and the effectiveness of the use of mineral and vitamin supplements in feeding cows of different technological groups. The analysis showed that the amount of calcium and phosphorus in the diets was close to the norm. Extremely high concentrations of elements such as magnesium, potassium and sodium were noted with an obvious lack of chlorine and sulfur. The cation-anion balance was positive: the range of indicators ranged from 14.98 to 23.49 and a tendency to increase this indicator by the end of lactation was revealed. The ratio of calcium and phosphorus, as well as potassium and sodium did not exceed the established norms. For most of the trace elements, the excess of the recommended norms was determined, which can be justified due to the low digestibility of trace elements in the body of cows.
\end{abstract}

\section{Introduction}

By the beginning of the 21st century, the intensification of processes in dairy farming led to an increase in the average milk yield of cows per lactation from 6 to 12 thousand $\mathrm{kg}$ of milk. High productivity of cows makes new demands on the technological aspects of livestock keeping [1-5]. An important role in these processes is played by the usefulness of cows' diets, in particular, the optimization of their mineral composition. So, V.I. Volgin, L.V. Romanenko, P.N. Prokhorenko, Z.L. Fedorova, E.A. Korochkina [6] in their studies note that the realization of the genetic potential of cattle depends by $25 \%$ on their provision with minerals and vitamins.

At the present stage of development of industrial cattle breeding, more and more large livestock enterprises are introducing intensive technologies for keeping cows, providing for year-round stall keeping. In such a situation, biologically active additives, which are of

\footnotetext{
*Corresponding author: fedosowa1986@mail.ru
} 
great importance in the intake of microelements into the body of animals, take on a large role in balancing the diets in terms of the macroelement composition.

The aim of the research was a comprehensive analysis of the usefulness of the mineral composition of the diets and the effectiveness of the use of mineral and vitamin supplements in the diets of cows of different technological groups.

The research tasks included:

- the study of the spectrum of mineral and vitamin supplements used to adjust the diets of cows of different technological groups;

- the analysis of the declared chemical composition of the additives used;

- the analysis of the usefulness of cows' diets in terms of macroelement and microelement composition;

- the analysis of the content of the main groups of synergists and antagonists.

\section{Materials and methods}

The studies were carried out on the basis of the Scientific Center for Laboratory Research of the Federal State Budgetary Educational Institution of Higher Education Ryazan State Agrotechnological University and one of the large agricultural holdings located in Ryazan region.

Dairy cows were assigned to different technological groups depending on the milk yield and the stage of lactation (Fig. 1).

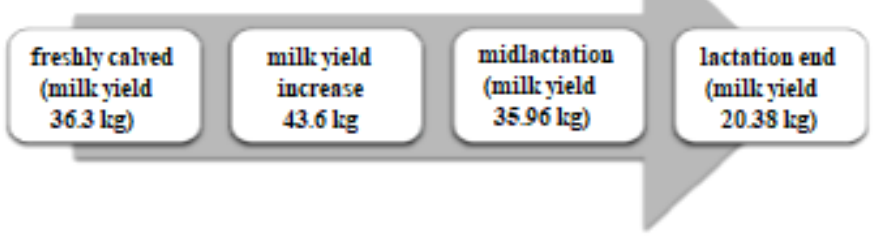

Fig. 1. The studied technological groups of cows.

In the course of the study, a comparative assessment of the chemical composition of mineral and vitamin feed additives of the Kaufit and Kaustart line was carried out. The study of the usefulness of the mineral composition of the diets was carried out by analyzing the content of macro- and microelements in the diet, as well as determining the ratio of groups of synergists and antagonists. The ratio of $\mathrm{Ca} / \mathrm{P}$ and $\mathrm{K} / \mathrm{Na}$ was calculated, the comparative content of $\mathrm{Ca}$ and $\mathrm{Mg}$ in the diet was analyzed.

\section{Results and discussion}

The analysis of the diets of dairy cows of a large livestock enterprise in Ryazan district of Ryazan region, belonging to different technological groups, made it possible to establish that Kaustart and Kaufit Immuno Fertil premixes produced by Mustang Feeding Technologies were used to balance the mineral composition of the diet (Table 1). 
Table 1. The range of mineral and vitamin supplements used to balance the diets of dairy cows

\begin{tabular}{|l|c|c|c|c|c|c|c|c|}
\hline \multirow{3}{*}{ Premix } & \multicolumn{7}{|c|}{ Content in the diet, kg } \\
\cline { 2 - 9 } & freshly calved & \multicolumn{2}{|c|}{$\begin{array}{c}\text { increasing the } \\
\text { milk yield }\end{array}$} & \multicolumn{2}{|c|}{ midlactation } & \multicolumn{2}{|c|}{ end of lactation } \\
\cline { 2 - 9 } & amount & DM & amount & DM & amount & DM & amount & DM \\
\hline Kaustart & 0.800 & 0.721 & 0.750 & 0.676 & - & - & - & - \\
\hline $\begin{array}{l}\text { Kaufit } \\
\begin{array}{l}\text { Immuno } \\
\text { Fertil }\end{array}\end{array}$ & 0.600 & 0.560 & 0.700 & 0.654 & 0.500 & 0.467 & - & - \\
\hline
\end{tabular}

The program for feeding mineral and vitamin supplements on the farm provides for the use of Kaustart and Kaufit Immuno Fertil in diets of freshly calved cows and animals increasing the milk yield. By the middle of lactation, Kaustart is excluded from the diet of cows, and by the end of lactation Kaufit Immuno Fertil also disappears.

The comparative analysis of the claimed chemical composition of the additives used shows that Kaustart includes only the main macronutrients such as calcium, phosphorus, magnesium and sodium (Table 2).

Table 2. The comparative analysis of the declared chemical composition of the additives used (in $1 \mathrm{~kg}$ of the product).

\begin{tabular}{|l|c|c|}
\hline \multicolumn{1}{|c|}{ Element } & Kaustart & Kaufit Immuno Fertil \\
\hline $\mathrm{Ca}, \mathrm{g}$ & 9 & 130 \\
\hline $\mathrm{P}, \mathrm{g}$ & 13 & 20 \\
\hline $\mathrm{Mg}, \mathrm{g}$ & 7 & 115 \\
\hline $\mathrm{Na}, \mathrm{g}$ & 90 & 90 \\
\hline $\mathrm{S}, \mathrm{g}$ & - & 5 \\
\hline $\mathrm{Mn}, \mathrm{mg}$ & - & 5,000 \\
\hline $\mathrm{Zn}, \mathrm{mg}$ & - & 8,000 \\
\hline $\mathrm{I}, \mathrm{mg}$ & - & 160 \\
\hline $\mathrm{Se}, \mathrm{mg}$ & - & 40 \\
\hline
\end{tabular}

According to the manufacturer's recommendation, Kaustart is used in the first two months after calving to prevent acidosis and reduce the number of ketone bodies.

In addition to macronutrients, Kaufit Immuno Fertil contains trace elements such as manganese, zinc, iodine and selenium.

According to the manufacturer, this premix is a basic feed additive for lactating cows. It should also be noted that the trace elements in the premix are in a chelated form, forming an organomineral complex. Chelated forms have a higher degree of bioavailability for the animal, providing a greater supply of microelements to the animal's body. E.V. Tuayeva [7], studying the use of chelated forms of microelements in rearing replacement calves, adds that the use of chelated forms activates the metabolism of replacements, which will contribute to an increase in subsequent milk production.

The second stage of the study was a comparative analysis of the mineral composition of the diets of cows of different technological groups (Tables 3 and 4).

Table 3. The content of macronutrients in the diets of dairy cows of different technological groups.

\begin{tabular}{|c|c|c|c|c|c|c|c|c|c|c|c|c|}
\hline \multirow[b]{2}{*}{ Element } & \multicolumn{3}{|c|}{ freshly calved } & \multicolumn{3}{|c|}{ increasing the milk yield } & \multicolumn{3}{|c|}{ midlactation } & \multicolumn{3}{|c|}{ end of lactation } \\
\hline & $\begin{array}{l}\text { in } 1 \mathrm{~kg} \\
\text { of } \mathrm{DM}, \mathrm{g}\end{array}$ & norm & $\begin{array}{l}\text { differe } \\
\text { nce, } \%\end{array}$ & $\begin{array}{l}\text { in } 1 \mathrm{~kg} \\
\text { of } \mathrm{DM}, \mathrm{g}\end{array}$ & norm & $\begin{array}{l}\text { differe } \\
\text { nce, } \%\end{array}$ & $\begin{array}{l}\text { in } 1 \mathrm{~kg} \\
\text { of } \mathrm{DM}, \mathrm{g}\end{array}$ & norm & $\begin{array}{l}\text { differe } \\
\text { nce, } \%\end{array}$ & $\begin{array}{l}\text { in } 1 \mathrm{~kg} \\
\text { of } \mathrm{DM} \text {, } \\
\mathrm{g}\end{array}$ & norm & $\begin{array}{l}\text { differe } \\
\text { nce, } \%\end{array}$ \\
\hline$P$ & 4.24 & 3.80 & 11.60 & 4.30 & 4.00 & 7.50 & 3.94 & 3.80 & 3.68 & 3.59 & 3.30 & 8.79 \\
\hline
\end{tabular}




\begin{tabular}{|l|c|c|c|c|c|c|c|c|c|c|c|c|}
\hline $\mathrm{Ca} / \mathrm{P}$ & 1.73 & - & - & 1.67 & - & - & 1.75 & - & - & 1.49 & - & - \\
\hline $\mathrm{Mg}$ & 2.41 & 1.68 & 43.45 & 2.28 & 1.70 & 34.12 & 2.13 & 1.68 & 26.79 & 1.93 & 1.60 & 20.63 \\
\hline $\mathrm{K}$ & 11.84 & 3.69 & 220.87 & 11.76 & 3.85 & 205.45 & 12.48 & 3.69 & 238.21 & 14.05 & 3.03 & 363.70 \\
\hline $\mathrm{Na}$ & 3.30 & 1.50 & 120.00 & 3.52 & 1.50 & 134.67 & 3.47 & 1.50 & 131.33 & 2.19 & 1.40 & 56.43 \\
\hline $\mathrm{K} / \mathrm{Na}$ & 3.59 & - & - & 3.34 & - & & 3.60 & - & & 6.41 & - & - \\
\hline $\mathrm{Cl} * *$ & 5.80 & 28.82 & -79.87 & 4.75 & 34.24 & -86.13 & 4.89 & 31.91 & -84.68 & 4.25 & 26.81 & -84.15 \\
\hline $\mathrm{S}^{*}$ & 2.13 & 21.50 & -90.09 & 1.90 & 23.00 & -91.74 & 1.88 & 21.50 & -91.26 & 1.60 & 16.00 & -90.00 \\
\hline
\end{tabular}

* The sulfur standard was determined according to Gruber tables for feeding dairy cows, replacement, sheep and goats.

** The chlorine standard was determined by the calculation method, based on the fact that the normal chlorine content should be $0.13 \%$ of the dry matter of the diet.

The analysis of the content of the main macronutrients showed that the diets were well balanced in terms of such macronutrients as calcium and phosphorus. Deviations from the normative parameters of the calcium content were in the range of 3.08-18.54 \%, and by the end of lactation, the excess of calcium in the diet was more and more leveled, approaching the norm. Deviations from the standard phosphorus content also decreased over time. And if in the group of freshly calved cows the excess of the norm was about $11.60 \%$, then by the end of lactation it decreased to $8.79 \%$.

It should be noted that according to research by scientists, an excess of calcium is well tolerated by cattle, although V.I. Volgin, L.V. Romanenko, P.N. Prokhorenko, Z.L. Fedorova, E.A. Korochkina [6] add that an excess of calcium leads to a decrease in the eatability and digestibility of feed, reducing the absorption of zinc and phytic acid, iodine, which leads to suppression and dysfunction of the thyroid gland.

The excess of phosphorus in the diet of cows, according to scientists, is not accompanied by any clinical signs for a long time, since animals can excrete excess phosphorus through saliva, urine and manure $[8,9]$. Nevertheless, excessive concentrations of phosphorus in the body knock down the self-regulation mechanism, disrupt the absorption of manganese, can lead to diarrhea, and in the dry period, excess phosphorus can increase the risk of milk paresis.

Continuing to analyze the macronutrient composition of the diets, one can note extremely high concentrations of elements such as magnesium, potassium and sodium with an obvious lack of chlorine and sulfur.

In most works devoted to the study of the effect of macronutrients on the body of animals, the situation with a lack of sodium is considered, which, in combination with an excessive concentration of potassium, disrupts reproduction processes $[9,10]$. However, it has been established that excess sodium in the body does not pose a danger to animals, provided there is unlimited access to drinking water.

Comparative analysis of the degree of nutritional balance in terms of macronutrients showed that potassium was characterized by the highest concentrations being 2-3 times higher than the norm. Its content was especially high in the diet of cows at the stage of attenuation of lactation. This situation is extremely dangerous, since an excess of potassium in the diet can lead to tetany and milk fever. The toxic dose of potassium with constant use is $30 \mathrm{~g} / \mathrm{kg}$ of the dry matter [11]. In the case under study, the dose of potassium ranges from 11.76 to $14.05 \mathrm{~g}$, increasing towards the end of lactation. This is far below the toxic threshold, but nevertheless raises certain concerns.

The main calcium antagonist, according to many scientists, is magnesium, which is a cofactor for enzymes and is involved in the conduction of impulses along the nerve fiber. The magnesium content in the analyzed diets exceeds the norm by 20.63-43.45\%. Longterm intake of excess magnesium, according to G.A. Yarmots [9] can intensify the processes of calcium excretion from bone tissue and some proteins. Clinical manifestations of excess magnesium in the diet may include hoof inflammation and mastitis [10].

Comprehensive studies of the macronutrient composition of diets also imply an analysis of the ratio between the content of individual elements. For the purpose of a deeper analysis 
of the usefulness of the chemical composition of the diets, an analysis of the cation-anion balance $(\mathrm{CAB})$ was carried out according to the standard method [8].

The calculated $\mathrm{CAB}$ indicator turned out to be positive and showed a tendency to increase from 14.98 in the group of freshly calved cows to 23.49 in the group of cows at the stage of dying lactation. A positive $\mathrm{CAB}$ is another indication of the current situation: high concentrations of $\mathrm{Na}^{+}$and $\mathrm{K}^{+}$ions against the background of low concentrations of $\mathrm{Cl}^{-}$and $\mathrm{S}^{2-}$.

Highly cationic (positive) $\mathrm{CAB}$, according to scientists, can be observed due to high levels of protein contained in feed. Rationing according to $\mathrm{CAB}$ is usually recommended to be carried out in a group of dry cows to reduce the risk of maternity paresis.

However, the lack of $\mathrm{Cl}^{-}$and $\mathrm{S}^{2-}$ anions in the diet of dairy cows can also lead to negative consequences. For example, V.I. Volgin, L.V. Romanenko, P.N. Prokhorenko, Z.L. Fedorova, E.A. Korochkina [6] note that the lack of chlorine in the diets of animals contributes to a decrease in the intensity of secretion of hydrochloric acid, an increase in the risk of digestive disorders. The lack of sulfur in ruminants leads to a decrease in feed intake, inhibits the synthesis of amino acids and microbial protein, as well as the digestibility of fiber in the rumen [12]. It is possible to balance the lack of sulfur by introducing fodder sulfur into the diet, for example, preparation "Ground fodder sulfur "Ration"" GOST 127.5-93.

The next stage of research was the analysis of the trace element composition of the diets (Table 4).

Table 4. Trace element composition of feed (in $1 \mathrm{~kg}$ of the dry matter), depending on the stage of lactation.

\begin{tabular}{|l|c|c|c|c|c|}
\hline Element & $\begin{array}{c}\text { freshly } \\
\text { calved }\end{array}$ & $\begin{array}{c}\text { increasing the } \\
\text { milk yield }\end{array}$ & midlactation & $\begin{array}{c}\text { end of } \\
\text { lactation }\end{array}$ & $\begin{array}{c}\text { Norm } \\
\text { (in 1 kg of the } \\
\text { dry matter) }\end{array}$ \\
\hline $\mathrm{Fe}, \mathrm{mg}$ & 152.1 & 115.8 & 112.8 & 100.9 & 50 \\
\hline $\mathrm{Zn}, \mathrm{mg}$ & 125.3 & 138.0 & 119.1 & 76.7 & 50 \\
\hline $\mathrm{Mn}, \mathrm{mg}$ & 108.6 & 118.0 & 103.7 & 68.0 & 50 \\
\hline $\mathrm{Cu}, \mathrm{mg}$ & 25.8 & 27.8 & 23.4 & 16.0 & 10 \\
\hline $\mathrm{I}, \mathrm{mg}$ & 0.9 & 1.0 & 0.8 & 0.5 & 0.5 \\
\hline $\mathrm{Co}, \mathrm{mg}$ & 0.6 & 0.6 & 0.4 & 0.2 & 0.1 \\
\hline $\mathrm{Se}, \mathrm{mg}$ & 0.5 & 0.5 & 0.4 & 0.3 & 0.25 \\
\hline
\end{tabular}

For standards of the main microelements in the diet of cattle, the amount of one or another element per head per day is usually taken and is adjusted depending on the expected productivity [11]. Nevertheless, there are also standards for the content of trace elements in $1 \mathrm{~kg}$ of the dry matter (Table 4), which have been used to analyze the usefulness of the micronutrient composition of the diet.

Studies have not revealed a deficiency in any of the studied trace elements. On the contrary, most of the elements in this group exceeded the recommended norms. The highest concentration excesses are characteristic of iron, zinc and manganese, the content of which is two times higher than the norm.

It should be added that according to studies, trace elements from feed are poorly absorbed [13]. So V.G. Ryadchikov [8] reports that assimilation of manganese does not exceed $2 \%$, zinc and copper - $15-20 \%$ and selenium - $40 \%$. If one considers this circumstance, then such an excess of the standards for the content of trace elements in the diet becomes sufficiently justified. However, micronutrient nutrition is worth paying close attention to.

Studying the complex effect of minerals, scientists have been able to determine the optimal ratio of some elements. In particular, when balancing diets, livestock specialists often pay attention to the ratio of calcium and phosphorus, potassium and sodium. 
So, the normative ratio of calcium and phosphorus, according to different scientists, is in the range of $1.5-2[8,11]$. Analysis of the $\mathrm{Ca} / \mathrm{P}$ ratio in the diets of cows belonging to different technological groups shows values close to the normative ones. They range from 1.49 to 1.75 .

When adjusting the $\mathrm{K} / \mathrm{Na}$ ratio, problems may arise with the correct determination of the standard indicators. Sh.K. Shakirov, N.N. Khazipov, F.S. Gibadullina, S.I. Churin faced this issue [14]. They note that according to data from various sources, a completely different ratio is considered optimal. Some researchers believe that it should be no more than 6 , while others call a much higher figure. According to the authors, some of the scientists believe that the $\mathrm{K} / \mathrm{Na}$ ratio, equal to 20 has no negative effects. This variance in regulatory performance is confusing and makes it difficult to adjust diets. Nevertheless, most scientists agree that a violation of the ratio of these elements in the diet will lead to adverse consequences.

When studying the ratio of potassium and sodium in the diets of cows, indicators were obtained in the range of 3.34-3.60. The exception was the group of cows at the stage of lactation completion. The $\mathrm{K} / \mathrm{Na}$ ratio in the diet of cows in this group was 6.41 , that was two times higher than in other groups. But, nevertheless, it could not be considered high.

Thus, when adjusting diets, it is necessary not only to balance the concentration of the main macro- and microelements mechanically, but also to penetrate deeply into the processes of interaction and metabolism of mineral substances, studying their synergistic and antagonistic relationships, which will ultimately lead to better results.

\section{Conclusion}

1. The diets were well balanced in macronutrients such as calcium and phosphorus. Deviations from the normative parameters of the calcium content were in the range of 3.08$18.54 \%$, and by the end of lactation, the excess of calcium in the diet was more and more leveled, approaching the normative indicators. Deviations from the standard phosphorus content also decreased over time.

2. Comparative analysis of the degree of balance of diets for macronutrients showed extremely high concentrations of such elements as magnesium, potassium and sodium with an obvious lack of chlorine and sulfur. The highest concentrations were observed for potassium being 2-3 times higher than the norm. Its content was especially high in the diet of cows at the stage of attenuation of lactation. The magnesium content in the analyzed diets exceeded the norm by $20.63-43.45 \%$.

3. The calculated $\mathrm{CAB}$ indicator turned out to be positive and showed a tendency to increase from 14.98 in the group of freshly calved cows to 23.49 in the group of cows at the stage of dying lactation.

4. Studies have not revealed a deficiency in any of the studied trace elements. On the contrary, most of the elements in this group exceeded the recommended norms. The greatest excess of concentration was characterized by iron, zinc and manganese, the content of which was two times higher than the norm.

5. The analysis of the $\mathrm{Ca} / \mathrm{P}$ ratio in the diets of cows belonging to different technological groups showed values close to the normative ones. The spread was from 1.49 to 1.75 . When studying the ratio of potassium and sodium in the diets of cows, indicators were obtained in the range of 3.34-3.60. The exception was the group of cows at the stage of completion of lactation. The $\mathrm{K} / \mathrm{Na}$ ratio in the diet of this group of cows was 6.41 . 


\section{References}

1. L. Kashirina, K. Ivanischev, K. Romanov, E3S Web of Conferences, 176 (2020)

2. I. Kondakova, E. Vologzhanina, J. Lomova, N. Kryuchkova, E3S Web of Conferences, $222(2020)$

3. I.Yu. Bystrova, O.A. Fedosova, G.V. Ulivanova, G.N. Glotova, E.N. Pravdina, E.A. Rydanova, International Journal of Advanced Biotechnology and Research, 10 (2019)

4. G.M. Tunikov, I.Yu. Bystrova, N.G. Byshova, Zh.S. Mayorova, E.N. Pravdina, K.K. Kulibekov, Journal of Advanced Biotechnology and Research, 10 (2019)

5. A.S. Emelyanova, L.G. Kashirina, S.D. Emelyanov, M.T. Trfandyan, J.E. Dorokhina IOP Conference Series: Earth and Environmental Science, 422(1) (2020)

6. V.I. Volgin, L.V. Romanenko, P.N. Prokhorenko, Z.L. Fedorova, E.A. Korochkina, Adequate feeding of dairy cattle is the basis for realizing the genetic potential of productivity, 260 (2018)

7. E.V. Tuayev, Scientific and practical substantiation of the use of chelated forms of microelements contained in natural fodder resources when growing replacement young animals, Dis. Doct. of Agr. Sc. 330 (2018)

8. V.G. Ryadchikov, Fundamentals of nutrition and feeding of farm animals: a training manual, 328 (2012)

9. G.A. Yarmots, Scientific and practical substantiation of the mineral nutrition of highly productive dairy cattle in the conditions of the northern Trans-Urals, Dis. Doct. of Agr. Sc. 336 (2014)

10. O.P. Pozyvailo, I.V. Kotovich, N.V. Dig, S.Yu. Zaitsev, Vesnik of MDPU Named after P. Shamyakin, 47, 1 (2016)

11. A.P. Kalashnikov, Rates and rations for feeding farm animals. Reference Guide, 456 (2003)

12. N.M. Belousov, T.V. Lycheva, Mineral and vitamin nutrition of cattle. Effective methods of balancing livestock rations in Western Siberia. Methodical instructions, 52 (2016)

13. A.A. Nazarova, I.A. Stepanova, G.I. Churilov, S.D. Polischuk, V.V. Churilova, D.G. Churilov, International Journal of Nanotechnology, 16 (2019)

14. Sh.K. Shakirov, N.N. Khazipov, F.S. Gibadullina, S.I. Churin, Recommendations for the rational use of carbohydrates (sugars), minerals and vitamins, 30 (2012) 